\title{
PHYTOCHEMICAL SCREENING, ISOLATION OF COUMARINS AND EXAMINING BIOACTIVITY OF PRANGOS PLATYCHLAENA BOISS. PLANT IN IRAQ
}

\author{
RAHMAN, J. K. $.^{*}-$ JAFF, D. M. A. ${ }^{2}-$ BASAR, ${ }^{3}{ }^{3}-$ KUTHI, N. A. ${ }^{3}-$ YAQUBU, R. ${ }^{4}$ \\ ${ }^{I}$ Department of Environmental Sciences, College of Science, University of Salahaddin-Erbil, \\ Kurdistan Region, Iraq \\ ${ }^{2}$ Department of Biology, College of Education, University of Salahaddin-Erbil, Kurdistan \\ Region, Iraq \\ ${ }^{3}$ Department of Chemistry, Faculty of Science, University Teknology Malaysia, 81310 Johor \\ Bahru, Malaysia \\ ${ }^{4}$ Department of Chemistry, Federal College of Education (FCE), Okene P. M .B. 1062, Kogi \\ State, Nigeria \\ *Corresponding author \\ e-mail: jwanbio9@gmail.com \\ (Received $17^{\text {th }}$ Nov 2019; accepted $30^{\text {th }}$ Jan 2020)
}

\begin{abstract}
The Prangos platychlaena Boiss. a wild plant belonging to the Apiaceae family, is a native plant of Kurdistan-Iraq. The roots, leaves, stem and flowers of the plant were collected in the Halgurd mountain of the Kurdistan region of Iraq, and extracted by petroleum ether, ethanol and water to obtain the crude extracts. Our results showed that the plant contains different phytochemicals that are distributed unequally in different parts. The chromatography technique was used for the isolation and purification of three coumarins (5,8-dimethoxy psoralen, 5-methoxy psoralen and 8-methoxy psoralen) from the parts of the flower, all compounds are new among the Prangos species. The extracts of different plant parts and isolated compounds showed anti-oxidant and anti-microbial activities against pathogenic bacteria and yeasts. These findings suggested that this plant, specially their leaves and flowers can be used for the treatment of some diseases in the future.
\end{abstract}

Keywords: antioxidant, Erbil, bacteria, yeast, psoralen

\section{Introduction}

Kurdistan region of Iraq is well known for the diversity of wild plants and their natural products, which have been used for a long time by its habitants as traditional medicine, fodder and for other purposes (Hamad et al., 2017). The current task is to identify the chemical compounds of the plant, facilitating its use in new medicines and may be assumed as therapies for treating many diseases with few side effects (Moradi et al., 2016). Apiaceae family in this aspect is regarded as one of the most important families, with its different plant species. The genus of Prangos belongs to the family of Apiaceae, having thirty species distributed from the Mediterranean to central Asia, seven species of them which are distributed in the Kurdistan region of Iraq, which are $P$. platychlaena Boiss., P. ferulacea (L.), P. uloptera DC., P. asperula Boiss., P. pabularia Lindl., $P$. peucedanifolia Fenz, and $P$. carymbosa Boiss. (Ghazanfar and Edmondson, 2013). Prangos platychlaena Boiss. is a perennial plant, length can reach up to 1-1.5 m. This plant is found naturally growing in the mountain of Kurdistan region, it contains 
different quantities of phytochemical compounds that have important roles in the biological activities and medicinal values of this plant.

Terpenoids in the plant may contribute against the microbial activity (Irfan et al., 2014), the alkaloid used to fight the oral intoxication (Matsuura and Fett-Neto, 2015), phenol compounds are considerably antimicrobial and the sources of antioxidants properties (Mariem et al., 2014) flavonoides and saponin compounds participate in antiviral, anti-inflammation, antioxidation and antimicrobial activities (Juca et al., 2018) (Desai et al., 2009) and tannines polyphenolic compounds are able to reduce the number of worm in the digestive tract of goat or sheep and also have great roles in the other biological activities (Wina et al., 2010). Based on the available literature the root, leaves, stem and flowers of $P$. platychlaena Bioss. has not been subjected to any investigation of this type. This is the first research performed on this species. As part of this study on the chemical constituents and their bioactivity of a different plant part of $P$. platychlaena Boiss. Thus, the work will concentrate on the chemical constituents, antioxidant and antimicrobial activities of the different plant parts.

\section{Materials and methods}

\section{Plant collection}

The different plant parts of $P$. platychlaena Boiss. were collected during June-July 2017 from the Halgurd mountain in the Kurdistan region of Iraq and shown in Figure 1, at the altitude of $2170 \mathrm{~m}$, Dr. Abdulah Shukur, a plant taxonomist at the department of biology, College of Education/Salahaddin University, was helping for the identification of this plant.

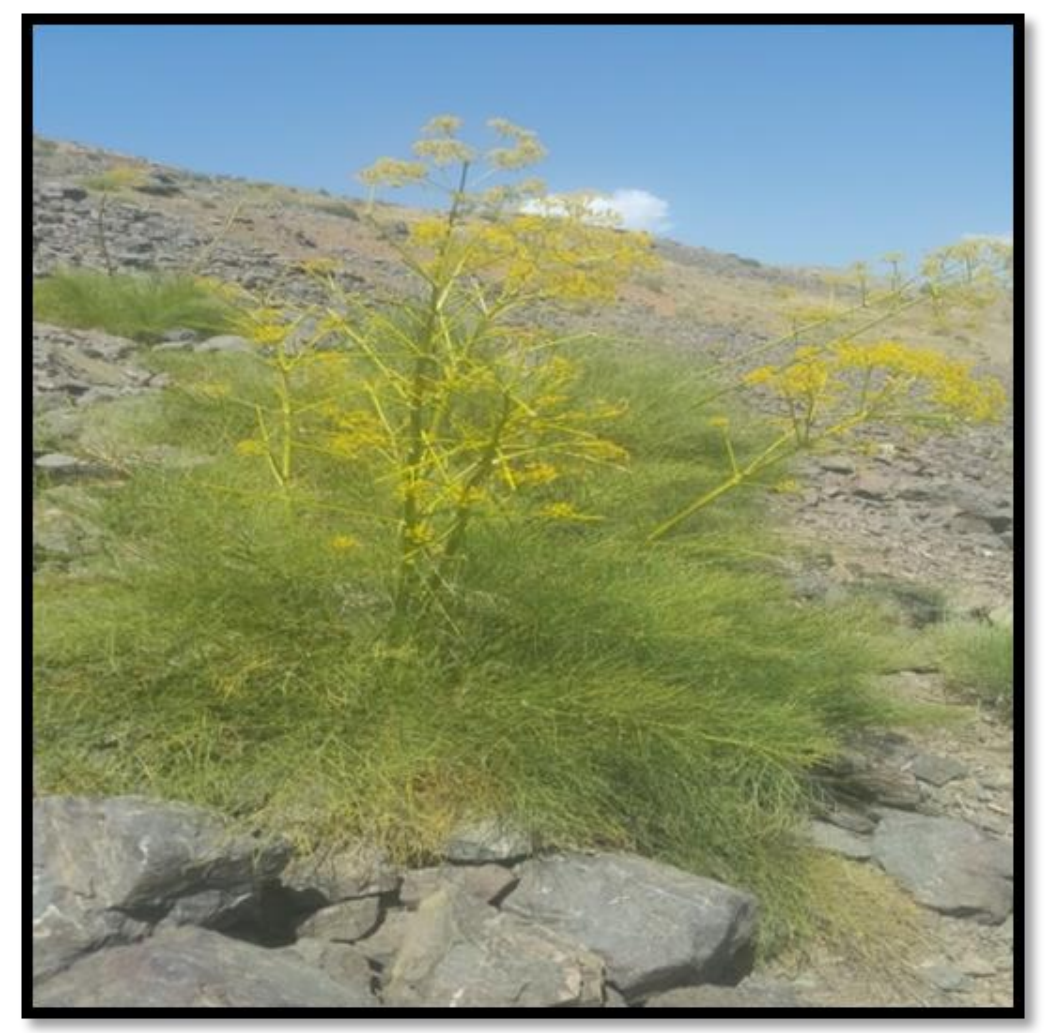

Figure 1. The whole plant of P. platychlaena Boiss. 


\section{Maceration extraction}

The different plant parts of the P. platychlaena Boiss. were collected, cleaned and shed dried at room temperature near $38{ }^{\circ} \mathrm{C}$ to constant weight and ground by grinders slowly. Dry powder of each plant part was extracted by using a solvent, with increasing polarity in the order of petroleum ether, ethanol and distilled water for three days at room temperature. The extract solution was concentrated using a rotary evaporator to obtain the crude extract.

\section{Phytochemicals screening in different plant part of Prangos platychlaena Boiss.}

Detection of terpenoid

In the test tube, a $5 \mathrm{ml}$ stock solution of extract was mixed with $2 \mathrm{ml}$ chloroform followed by $2 \mathrm{ml}$ concentrated $\mathrm{H}_{2} \mathrm{SO}_{4}$. A reddish brown coloration has suggested the presence of terpenoids (Mujeeb et al., 2014).

\section{Test for alkaloid}

To $10 \mathrm{ml}$ of the extract solution, $0.4 \mathrm{ml}$ of $\mathrm{HCl}(1 \%)$ was added to a solution, followed by 6 drops of Dragendroff reagent, the brownish-red precipitate indicated the presence of alkaloids (Mujeeb et al., 2014).

\section{Phenol detection test}

Lead acetate test: Two drops of lead acetate solution (10\%) was added to $2 \mathrm{ml}$ of plant extract solution. The formation of a bulky white precipitate showed the presence of phenolic compounds (Singh and Bag, 2013).

\section{Detection of flavonoid (Alkaline reagent)}

In this test, two drops of diluted $\mathrm{NaOH}(10 \%)$ solution were added to the stock solution of the plant $(2 \mathrm{ml})$, an intense yellow coloration showed the presence of flavonoid compounds (Hossain et al., 2013).

\section{Detection of saponin}

In this test, $10 \mathrm{ml}$ of the plant extraction solution was taken in the test tube. It was shaken vigorously by hand for $2 \mathrm{~min}$, the formation of stable foam indicated the presence of saponins (Mandal et al., 2013).

\section{Tannin detection test}

Two drops of $\mathrm{FeCl}_{3}(1 \%)$ were added to the plant extract solution, the blue-black or blue- green coloration appeared as an indicator for the presence of tannin (Bankole et al., 2016).

\section{Isolation and identification of compounds in P. platychlaena Boiss.}

\section{General procedure}

Normal extraction technique was applied to the dried powder of flower $P$. platychlaena Boiss. in the laboratory of the Chemistry Department of University Technology of Malaysia. Vacuum liquid chromatography (VLC) was performed using 
silica gel 60 (230-400 mesh), and gravity column chromatography (CC) was carried out using Merck silica gel 60(70-230 mesh). Silica gel aluminum sheets (Merck Kieselgel $60 \mathrm{~F} 254,0.20 \mathrm{~mm}$ ) were used for Thin layer chromatography (TLC) analysis of crude extract, fraction and isolation of pure compounds. Spots on TLC were observed under UV light at $254 \mathrm{~nm}$ and $365 \mathrm{~nm}$, followed by spraying vanillin sulphuric acid reagent and heating at $120^{\circ} \mathrm{C}$ on a hot plate for $5 \mathrm{~min}$. Infrared (IR) spectra were measured using the Perkin Elmer series 1600 FT-IR spectrophotometer with a $\mathrm{KBr}$ pellet for a solid sample. Melting points were measured using a hot stage Leica Gallen apparatus with a microscope and were uncorrected. Nuclear Magnetic Resonance (NMR) Bruker Advance 400 Spectrometer (400/100 MHZ) was used to measure ${ }^{1} \mathrm{H},{ }^{13} \mathrm{C}$ and correlation spectroscopy (COSY) spectra by using Deuterated chloroform-d as a solvent. Mass spectral data were obtained using Gas Chromatography (GC) and Bruker Mass Spectroscopy (MS) services at the Department of Chemistry, National University of Singapore, Singapore.

\section{5, 8- Dimethoxy psoralen (Isopimpinellin) (1)}

The petroleum ether crude extract of the flower of P. platychlaena Boiss. $(6.0 \mathrm{~g})$ was subjected to silica gel VLC $(285.0 \mathrm{~g}$, column size: $14.0 \times 11.0 \mathrm{~cm})$, the solvent system: n-hexane, n-hexane -chloroform, chloroform-ethyl acetate, acetone (100\%) and methanol $(100 \%)$ in order of increasing polarity to give 13 fractions, each fraction was subjected to TLC analysis. Finally, the single (colorless) spot showed indicated Isopimpinellin.

\section{5-Methoxy psoralen (2)}

The petroleum ether extract was partitionated from ethanol extract $(2.85 \mathrm{~g})$ of $P$. platychlaena Boiss. The flower was subjected to silica gel VLC column, eluted with nhexane: chloroform: ethyl acetate: methanol: acetone in step gradient to give thirteen fractions. The fraction 4, fraction 5 and fraction 7 were selected and mixed for further purification by silica gel column chromatography, the single (colorless) spot showed indicated 5-Methoxy psoralen.

\section{8-Methoxy psoralen (3)}

The extract of diethyl ether $(1.41 \mathrm{~g})$ of $P$. platychlaena Boiss. flower was subjected to silica gel VLC, the solvent system: n-hexane, n-hexane -chloroform, chloroformethyl acetate, acetone and methanol in order of increasing polarity to give thirteen fractions. The $2^{\text {nd }}$ fraction was used for further purification by silica gel column chromatography, the single (colorless) spot showed indicated 8-Methoxy psoralen.

\section{Bioactivity of different plant parts of P. platychlaena Boiss.}

\section{Antioxidant activity (DPPH assay)}

The antioxidant activity (A\%) of the sample was assayed according to the method described by Giweli et al. (2012). The standard DPPH (2,2-diphenylpicrylhydrazyl) assay was carried out using 96 -well sterile micro plates. DPPH solution $(0.04 \%)$ in methanol was prepared, the stock solution of the samples was prepared in methanol. $200 \mu \mathrm{L}$ of the stock solution of sample was added to the first column and the rest of the wells were filled with $100 \mu \mathrm{L}$ of methanol, next, $100 \mu \mathrm{L}$ content of the first well was 
transferred into the next well of the same raw of the microplate, this procedure was repeated for the following well of the same row to obtain a serial dilution of extraction. $100 \mu \mathrm{L}$ DPPH solution was added to all well except for the blank well, while methanol $(100 \mu \mathrm{L})$ and $100 \mu \mathrm{L}$ DPPH solution was added to the control well. The plate was shaken for mixing the solution and incubated for $30 \mathrm{~min}$ in the dark at room temperature. The absorbance value of each well was measured at a wavelength of $517 \mathrm{~nm}$, using a microplate reader. Ascorbic acid was used as a positive control, the DPPH radical scavenging activity at different concentrations was calculated by the following equation employed by Ahmed et al. (2015).

$$
\% \mathrm{~A}=\mathrm{A}_{\mathrm{c}}-\mathrm{A}_{\mathrm{s}} / \mathrm{A}_{\mathrm{c}} \times 100
$$

where, $\% \mathrm{~A}$ is the percentage of antioxidant activity, $\mathrm{A}_{\mathrm{c}}$ is the absorbance of the control and $A_{s}$ is the absorbance of the sample. The lower absorbance of the reaction mixture indicated a higher free radical scavenging activity and the color of the reaction change from violet to yellow color. The $\mathrm{IC}_{50}$ value $(\mathrm{mg} / \mathrm{ml})$ was the concentration of the sample required to scavenge $50 \%$ of the DPPH free radical.

\section{Antimicrobial activity of P. platychlaena Boiss.}

Microbial strain

The in vitro antimicrobial activities of the extract and pure compound were carried out by using pathogenic bacteria such as Pseudomonas aeruginosa ATCC 9027, clinical Pseudomonas aeruginosa, Staphylococcus aureus ATCC 6538P, and clinical Staphylococcus aureus. The clinical pathogen bacteria isolated from humans were obtained from the Media Diagnostic Health Center in Erbil. While pathogenic yeast such as Candida albicans, and Candida parapsilosis were obtained from the Biology Department, College of Science, University of Salahadden-Erbil, Iraq. The yeasts were isolated from humans and identified by Dr. Hero Muhammed Ismael.

Culture media and activation of microbial strain

The medium of the Sabouraud Dextrose broth and Mueller-Hinton broth were used for the cultivation of fungi and bacteria, respectively. The inocula were prepared by transferring several single colonies of microbes into a sterile broth media and mixed together, then incubated at $37^{\circ} \mathrm{C}$ for overnight. Inoculum of the culture solution was adjusted to the McFarland scale 0.5 and confirmed by spectrophotometrical reading at $580 \mathrm{~nm}$ (Ginovyan et al., 2017).

\section{Evaluation of antimicrobial activities}

Antimicrobial activities of the extracts and pure compounds were assessed by the Microdilution method according to previous methods (Bacha et al., 2016; Silva et al., 2011), this was used for determining the minimum Inhibitory Concentration (MIC) of the $P$. platychlaena Boiss. The assay was carried out in 96-well sterile micro plates, then, $100 \mu \mathrm{l}$ of nutrient broth was added to each well of the microplate. The first well was filled with $100 \mu \mathrm{l}$ of the sample, prepared at a concentration of $\mathrm{mg} / \mathrm{ml}$. Next, by transferring $100 \mu \mathrm{l}$ content from the first well into the next well of the same row of the microplate, after mixing the content of the well, this procedure was repeated for the 
following well of the same row to obtain serial dilution, in this case, the concentration of the sample will decrease. While pure dimethyl sulfoxide and broth media were used as a negative control, whereas Ketoconazol (antifungal) and Ciprofloxacin (antibacterial) were considered as references. For each well a microbial suspension of the working solution was inoculated. The absorbance for each well was measured at $630 \mathrm{~nm}$ before incubation time; by using ELISA microplate reader, the microplate was incubated at $37^{\circ} \mathrm{C}$ for $24 \mathrm{~h}$ for the growth of microbes. The absorbance was remeasured after incubation time to compare with the initial measurement. The MIC was calculated at the break point concentrations by comparing the absorbance before and after incubation time.

\section{Statistical analysis}

The antioxidant and antimicrobial activity of $P$. platychlaena Boiss. were statistically analyzed using the Kruskal- Wallis test and Dunn's multiple comparison test by Graph Pad-Prism version 7. All results arranged as mean \pm SE for each property and $P$ value less than 0.05 considered as statistically significant differences among them.

\section{Result and discussion}

According to the available literature, this is the first study on the phytochemical contents and bioactivity of the $P$. platychlaena Boiss.

\section{Phytochemical screenings in different plant part of P. platychlaena Boiss.}

Due to the fact that plant extracts usually occur as a combination of various types of phytochemicals and bioactive compounds with different polarities, their separation still remains a big demand for the process of isolation, identification and characterization of active compounds.

Qualitative chemical analysis was conducted by using petroleum ether, ethanol and water extract of roots, leaves, stem and flowers of the P. platychlaena Boiss. The data revealed the presence of terpenoids, alkaloids, polyphenols, flavonoids, saponins and tannins as major phytochemical groups and the results designated as $(+)$ for the presence and (-) for absence of phytochemicals (Table 1). The results showed the diversity of phytochemical distribution in the $P$. platychlaena Boiss. plant parts.

\section{Isolation and purification of compounds in P. platychlaena Boiss.}

The structures of the isolated compounds (5,8 dimethoxy psoralen, 5-Methoxy psoralen and 8-Methoxy psoralen) from flower P. platychlaena, were determined by using IR, ${ }^{1} \mathrm{H}-\mathrm{NMR},{ }^{13} \mathrm{C}-\mathrm{NMR}$, COSY, GC and MS spectrum.

\section{5,8-dimethoxy psoralen (1)}

Pale-yellow solid with m.p. $117.05^{\circ} \mathrm{C}, \mathrm{R}_{f}$. 0.3 in petroleum ether: chloroform (3:2). IR $v_{\max }(\mathrm{ATR}) \mathrm{cm}^{-1}: 1718(\mathrm{C}=\mathrm{O}), 1593(\mathrm{C}=\mathrm{C}), 1478(\mathrm{C}=\mathrm{C}), 1170(\mathrm{C}-\mathrm{O}), 1092(\mathrm{C}-$ O). GC: major peak at $\mathrm{t}_{\mathrm{R}} 29.06 \mathrm{~min}$. MS (EIMS): $\mathrm{m} / \mathrm{z} 246(87 \%)[\mathrm{M}]^{+}\left(\mathrm{C}_{13} \mathrm{H}_{10} \mathrm{O}_{5}\right), 231$ (100\%), 203 (19\%), 188 (23\%), 175 (22\%), 160 (16\%), 147 (13\%), $132(5 \%), 119$ (4\%), 104 (9\%), 76 (12\%). ${ }^{1} \mathrm{H}-\mathrm{NMR}\left(400 \mathrm{MHz}, \mathrm{CDCl}_{3}\right): 4.19\left(\mathrm{~s}, 2 \mathrm{x} \mathrm{OCH}_{3}\right), 6.32$ (d, $J=10.0 \mathrm{~Hz}, \mathrm{H}-3), 7.02$ (d, $J=2.4 \mathrm{~Hz}, \mathrm{H}-3$ ') 7.65 (d, $J=2.4 \mathrm{~Hz}, \mathrm{H}-2$ '), 8.16 (d, 
$J=10.0 \mathrm{~Hz}, \mathrm{H}-4) .{ }^{13} \mathrm{C}-\mathrm{NMR}\left(300 \mathrm{MHz}, \mathrm{CDCl}_{3}\right): 60.8\left(8-\mathrm{OCH}_{3}\right), 61.9\left(5-\mathrm{OCH}_{3}\right), 105.2$ (C-3'), 107.7 (C-10), 112.9 (C-3), 114.9 (C-6), 128.2 (C-8), 139.6 (C-4), 143.8 (C-9), $144.5(\mathrm{C}-5), 145.2(\mathrm{C}-2$ '), $149.9(\mathrm{C}-7), 160.7(\mathrm{C}=\mathrm{O})$ (Figures A1-A6) (Dincel et al., 2013).

Table 1. Qualitative phytochemical analysis of various extracts of different plant parts of Prangos platychlaena Boiss.

\begin{tabular}{c|c|c|c|c|c|c|c}
\hline Extracts & Plant parts & Ter. & Alk. & Phe. & Fla. & Sap. & Tan. \\
\hline \multirow{4}{*}{ Petroleum ether } & Root & + & - & + & - & - & - \\
& Leaves & + & - & + & - & - & - \\
& Stem (front) & + & - & + & - & - & - \\
& Flowers & + & - & + & - & - & - \\
\hline \multirow{5}{*}{ Ethanol } & Root & - & + & - & + & - & - \\
& Leaves & - & + & + & + & - & + \\
& Stem (front) & - & + & - & + & - & - \\
& Flowers & - & + & + & + & - & + \\
\hline \multirow{5}{*}{ Water } & Root & - & - & + & - & + & - \\
& Leaves & - & - & + & + & + & + \\
& Stem (front) & - & - & + & + & + & - \\
& Flowers & - & - & + & + & + & + \\
\hline
\end{tabular}

-: Absent, +: Present, Terpeniod: Ter, Alkaloid: Alk, Phenol: phe, Flavonoid: Fla, Saponin: Sap, Tannin: Tan.

\section{5-Methoxy psoralen (2)}

White crystals with m.p. $185^{\circ} \mathrm{C} . \mathrm{R}_{f}: 0.5$ in petroleum ether: chloroform (3:2). IR $v_{\max }$ (ATR) $\mathrm{cm}^{-1} 1727(\mathrm{C}=\mathrm{O}), 1624(\mathrm{C}=\mathrm{C}), 1606(\mathrm{C}=\mathrm{C}), 1580(\mathrm{C}=\mathrm{C}), 1468(\mathrm{C}=\mathrm{C})$, 1155 (C-O), 1076 (C-O). GC: single peak at $\mathrm{t}_{\mathrm{R}} 26.61 \mathrm{~min}$. MS (EIMS): $\mathrm{m} / \mathrm{z} 216(100 \%)$ $[\mathrm{M}]^{+}\left(\mathrm{C}_{12} \mathrm{H}_{8} \mathrm{O}_{4}\right), 201(31 \%), 188(13 \%), 173(65 \%), 145(20 \%), 89$ (38\%). ${ }^{1} \mathrm{H}-\mathrm{NMR}$ $\left(400 \mathrm{MHz}_{\mathrm{CDCl}}\right): 4.28\left(\mathrm{~s}, \mathrm{OCH}_{3}\right), 6.30(\mathrm{~d}, J=13.2 \mathrm{~Hz}, \mathrm{H}-3), 7.03$ (d, $J=3.2 \mathrm{~Hz}, \mathrm{H}-$ 3'), 7.27 (s, H-5), 7.61 (d, $J=3.2 \mathrm{~Hz}, \mathrm{H}-2$ '), 8.17 (d, $J=13.2 \mathrm{~Hz}, \mathrm{H}-4)$. ${ }^{13} \mathrm{C}-\mathrm{NMR}(300$ $\left.\mathrm{MHz}, \mathrm{CDCl}_{3}\right)$ : $60.2\left(5-\mathrm{OCH}_{3}\right), 105.1$ (C-3'), 106.4 (C-10), 112.6 (C-6), 112.6 (C-3), 139.4 (C-4), 145.0 (C-2'), 149.6 (C-5), 152.8 (C-9), 158.5 (C-7), 161.4 (C = O) (Figures A6-A12) (Dincel et al., 2013).

\section{8-Methoxy psoralen (3)}

White crystals with m.p. $140{ }^{\circ} \mathrm{C} . \mathrm{R}_{f} 0.4$ in petroleum ether: chloroform (3:2) IR (ATR) $\mathrm{cm}^{-1} 1704(\mathrm{C}=\mathrm{O}), 1617(\mathrm{C}=\mathrm{C}), 1583(\mathrm{C}=\mathrm{C}), 1454(\mathrm{C}=\mathrm{C}), 1150(\mathrm{C}-\mathrm{O}), 1023$ (C-O). GC: single peak at $\mathrm{t}_{\mathrm{R}} 26.88 \mathrm{~min}$. MS (EIMS): $\mathrm{m} / \mathrm{z} 216(100 \%)[\mathrm{M}]^{+}\left(\mathrm{C}_{12} \mathrm{H}_{8} \mathrm{O}_{4}\right)$ 201 (30\%), 188 (9\%), 173 (62\%), 145 (41\%), 89 (17\%). ${ }^{1} \mathrm{H}-\mathrm{NMR}$ (400 MHz, $\mathrm{CDCl}_{3}$ ): $4.31\left(\mathrm{~s}, \mathrm{OCH}_{3}\right), 6.38$ (d, $\left.J=12.8 \mathrm{~Hz}, \mathrm{H}-3\right), 6.8$ (d, $J=2.8 \mathrm{~Hz}, \mathrm{H}-3$ '), 7.37 (s, H-5), 7.70 $\left(\mathrm{d}, J=2.8 \mathrm{~Hz}, \mathrm{H}-2^{\prime}\right), 7.78(\mathrm{~d}, J=12.8 \mathrm{~Hz}, \mathrm{H}-4) .{ }^{13} \mathrm{C}-\mathrm{NMR}\left(300 \mathrm{MHz}, \mathrm{CDCl}_{3}\right): 61.3(8-$ $\mathrm{OCH}_{3}$ ), 106.7 (C-3'), 112.9 (C-5), 114.8 (C-3), 116.6 (C-10), 126.0 (C-6), 132.8 (C-8), 143.1 (C-9), 144.5 (C-4), $146.8(\mathrm{C}-2$ '), $147.6(\mathrm{C}-7), 160.6(\mathrm{C}=\mathrm{O})$ (Figures A12-18) (Dincel et al., 2013; Luz et al., 2015). 


\section{Bioactivity of Prangos platychlaena Boiss. extract of different parts}

\section{Antioxidant content}

Table 2 showed the antioxidant activity of the P. platychlaena Boiss. extracts, which were analyzed using the DPPH free radical scavenging method. The total antioxidant activity of the $P$. platychlaena Boiss. extracts increased with an increased concentration of the sample. The low value of $\mathrm{IC}_{50}$ shows the high antioxidant content. A significant difference $(\mathrm{P}<0.05)$ was noted among the antioxidant activities of the plant parts in different solvents. It has been shown that the $\mathrm{IC}_{50}$ of the petroleum ether extract of $P$. platychlaena Boiss. root, leaves, stem and flower were (1.02 $\pm 0.04,0.68 \pm 0.01$, $0.70 \pm 0.03$ and $0.19 \pm 0.01 \mathrm{mg} / \mathrm{ml}$ ) respectively, and the significant differences were increasing between root and flower parts. It was observed that petroleum ether extract of the flower of $P$. platychlaena Boiss. has higher antioxidant activity than the other parts. The activity effectiveness can be classified as follows: flower $>$ leaves $>$ stem $>$ root. As well as, the $\mathrm{IC}_{50}$ of the ethanol extraction for root, leaves, stem and flower were $(1.16 \pm 0.12,0.61 \pm 0.01,1.12 \pm 0.19$ and $0.67 \pm 0.01 \mathrm{mg} / \mathrm{ml})$, respectively, and the statistical analysis showed that the significant increasing of the results was present between the root and leaves parts. The data reported that extraction of the leaf parts of $P$. platychlaena Boiss. showed higher antioxidant potential than the other parts, this activity can be classified as: leaves $>$ flowers $>$ stem $>$ root. While, the $\mathrm{IC}_{50}$ value of the water extractions of different plant part (root, leaves, stem and flower) were $(1.13 \pm 0.14,0.84 \pm 0.02$, $0.83 \pm 0.01,0.54 \pm 0.02 \mathrm{mg} / \mathrm{ml}$ ), respectively, also the antioxidant values between root and flower parts were significantly increasing. This finding indicated that the flower part has a higher antioxidant potential than the other parts, this activity can be classified as: flowers $>$ stem $>$ leaves $>$ root. These results showed that the plant extracts inhibited the DPPH radical but in different manners, the variation observed among the plant part extracts, may be depending on the plant part and their growth stages, and unequal distribution of the polyphenols and flavonoids which have important roles in antioxidant activities (Sylvie et al., 2014).

Table 2. Antioxidant content $\left(I C_{50}\right)$ of different plant parts of $P$. platychlaena Boiss.

\begin{tabular}{c|c|c}
\hline Extracts & Plant parts & IC $_{\mathbf{5 0}}(\mathbf{m g} \mathbf{g})$ \\
\hline \multirow{3}{*}{ Petroleum ether } & Root & $1.02 \pm 0.04^{*}$ \\
& Leaf & $0.68 \pm 0.01$ \\
& Stem & $0.7 \pm 0.03$ \\
& Flower & $0.19 \pm 0.01^{*}$ \\
\hline \multirow{3}{*}{ Ethanol } & Root & $1.16 \pm 0.12^{*}$ \\
& Leaf & $0.61 \pm 0.01^{*}$ \\
& Stem & $1.12 \pm 0.19$ \\
& Flower & $0.67 \pm 0.01$ \\
\hline \multirow{2}{*}{ Distilled water } & Root & $1.13 \pm 0.14^{*}$ \\
& Leaf & $0.84 \pm 0.02$ \\
& Stem & $0.83 \pm 0.01$ \\
& Flower & $0.54 \pm 0.02^{*}$ \\
\hline
\end{tabular}

Values are mean $\pm \mathrm{SD}$, Symbol *: it means significantly with data caring the same symbol in the same extract 
Antimicrobial activities of P. platychlaena Boiss.

The antimicrobial activity of the plant extracts was implemented against Staphylococcus aureus ATCC 6538P, clinical Staphylococcus aureus, Pseudomonas aeruginosa ATCC 9027, clinical Pseudomonas aeruginosa, Candida albicans, and Candida parapsilosis were studied by using the microdilution method and their potency was assessed by the corresponding MIC value, and the results are shown in Tables 3 and 4 . The petroleum ether extracts of $P$. platychlaena Boiss. for leaves showed higher activities against $S$. aureus ATCC 6538P, clinical $S$. aureus, clinical $P$. aeruginosa, $C$. albicans, and $C$. parapsilosis, with the lowest MIC values of $0.23,1.16,1.33,0.74$ and $0.87 \mathrm{mg} / \mathrm{ml}$, respectively, these values were significantly higher than those of other parts of plant.

Table 3. Antibacterial activities of different plant parts of P. platychlaena Boiss.

\begin{tabular}{|c|c|c|c|c|c|c|}
\hline \multicolumn{2}{|c|}{ Samples } & \multirow[b]{2}{*}{ Plant parts } & \multicolumn{4}{|c|}{$\mathrm{MIC}(\mathrm{mg} / \mathrm{ml})$} \\
\hline \multirow{13}{*}{ Extracts } & \multirow{5}{*}{$\begin{array}{l}\text { Petroleum } \\
\text { ether }\end{array}$} & & $\begin{array}{c}\text { S. aureus } \\
\text { ATCC6538P }\end{array}$ & S. aureus & $\begin{array}{c}\text { P. aeruginosa } \\
\text { ATCC } 9027\end{array}$ & $\begin{array}{c}P . \\
\text { aeruginosa }\end{array}$ \\
\hline & & Root & $0.83 \pm 0.20$ & $2.66 \pm 0.16$ & $1.41 \pm 0.08$ & $5 \pm 0.00^{*}$ \\
\hline & & Leaves & $0.23 \pm 0.03^{*}$ & $1.16 \pm 0.08^{*}$ & $1.16 \pm 0.08$ & $1.33 \pm 0.08^{*}$ \\
\hline & & Stem & $0.86 \pm 0.13$ & $2.66 \pm 0.16$ & $1.23 \pm 0.01$ & $4.16 \pm 0.83$ \\
\hline & & Flowers & $1.16 \pm 0.08^{*}$ & $4.33 \pm 0.66^{*}$ & $1.21 \pm 0.11$ & $4.66 \pm 0.33$ \\
\hline & \multirow{4}{*}{ Ethanol } & Root & $1.66 \pm 0.41$ & $10.0 \pm 0.0^{*}$ & $1.33 \pm 0.08$ & $8.33 \pm 1.66$ \\
\hline & & Leaves & $2.16 \pm 0.16$ & $10 \pm 0.0^{* * *}$ & $4.16 \pm 0.83^{*}$ & $4.5 \pm 0.28^{*}$ \\
\hline & & Stem & $2.66 \pm 0.166^{*}$ & $10 \pm 0.0^{*}$ & $10.0 \pm 0.66^{* *}$ & $10.67 \pm 0.66$ \\
\hline & & Flowers & $1.04 \pm 0.20^{*}$ & $2.66 \pm 0.1^{*, * *, * * * *}$ & $1.16 \pm 0.08^{*, * *}$ & $8.33 \pm 1.66$ \\
\hline & \multirow{4}{*}{ Water } & Root & $>10$ & $>10$ & $>10$ & $>10$ \\
\hline & & Leaves & $>10$ & $>10$ & $>10$ & $>10$ \\
\hline & & Stem & $>10$ & $>10$ & $>10$ & $>10$ \\
\hline & & Flowers & $>10$ & $>10$ & $>10$ & $>10$ \\
\hline \multicolumn{2}{|c|}{ 5,8-dimethoxy psoralen } & & $1.33 \pm 0.16$ & $1.43 \pm 0.29$ & $2.5 \pm 0.5$ & $3.16 \pm 0.44$ \\
\hline \multicolumn{2}{|c|}{ Ciprofloxacin } & & $1.0 \pm 0.28$ & $1.66 \pm 0.33$ & $1.0 \pm 0.28$ & $2.33 \pm 0.33$ \\
\hline
\end{tabular}

Values are mean $\pm \mathrm{S} \mathrm{D}$, Symbol $* * *, * * *$ : it means significantly with data carrying the same symbol in the same extracts and in the same pathogen

While the activity of flower ethanol extraction showed more activity against $S$. aureus ATCC 6538P, clinical S. aureus, P. aeruginosa ATCC 9027, C. albicans, and $C$. parapsilosis with the lowest MIC values of 1.04, 2.66, 1.16, 4.5, 2.5 and $3.36 \mathrm{mg} / \mathrm{ml}$, respectively. The statistical analysis showed significant differences among the ethanol extractions of different plant parts. Whereas, the MIC values of the water extracts of different plant parts against the pathogen bacteria and yeasts were more than $10 \mathrm{mg} / \mathrm{ml}$. The statistical analysis showed that the extraction of different plant parts of the $P$. platychlaena Boiss. have significant differences $(\mathrm{p}<0.05)$ against the $S$. aureus ATCC 6538P, clinical $S$. aureus, $P$. aeruginosa ATCC 9027, clinical $P$. aeruginosa, $C$. albicans, and $C$. parapsilosis. 
Table 4. Anti-yeast activities of the different plant parts of Prangos platychlaena Boiss.

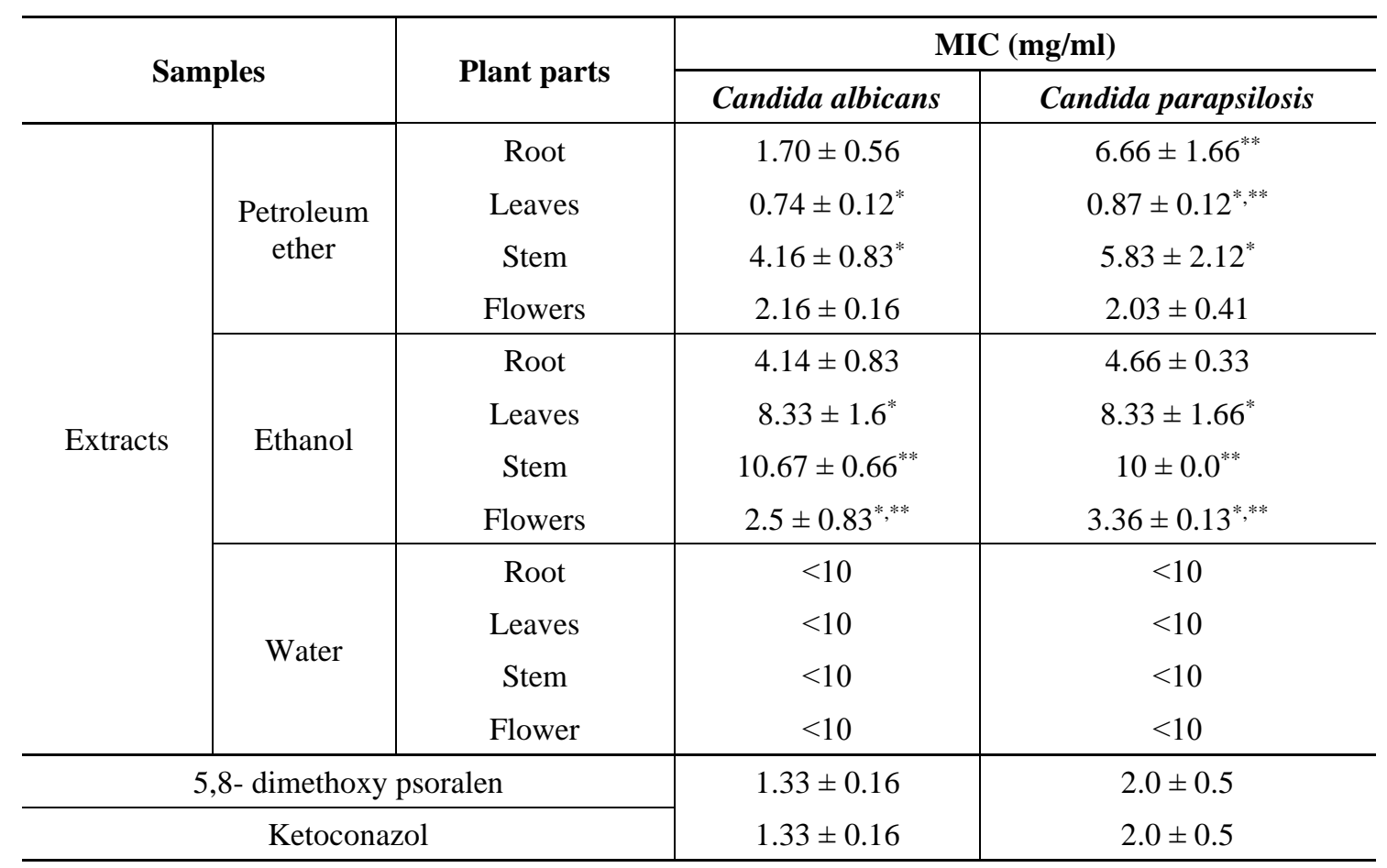

Values are mean $\pm \mathrm{SD}$, Symbol $* * *$ : it means significantly with data carrying the same symbol in the same extracts and in the same pathogen

While, the MIC values of the compound 5,8- dimethoxy psoralen for both strain $S$. aureus were 1.33 and $1.43 \mathrm{mg} / \mathrm{ml}$ and for both strains of $P$. aeruginosa were 2.5 and $3.16 \mathrm{mg} / \mathrm{ml}$, respectively, our result disagreed with those findings of Mbah et al. (2010), that concluded the 5,8- dimethoxy psoralen does not have antibacterial activities against pathogen bacteria. As well as, MIC values of the 5,8- dimethoxy psoralen for both $C$. albicans and $C$. parapsilosis were 1.33 and $2.0 \mathrm{mg} / \mathrm{ml}$, respectively. We have not more amount of 5-Methoxy psoralen and 8-Methoxy psoralen for microbial activities. Whereas, the MIC values of Ciprofloxacin for both strains of $S$. aureus were 1.0 and 1.66 , and also for both strains of $P$. aeruginosa were 1.0 and $2.33 \mathrm{mg} / \mathrm{ml}$, respectively. While, the MIC values of Ketoconazol for C. albicans, and C. parapsilosis were 1.33 and $2.0 \mathrm{mg} / \mathrm{ml}$, respectively. Also, when all MIC values of the extraction compared to both Ciprofloxacin and Ketoconazol, showed the extracts of this plant were close or better than antimicrobial references. All data obtained in this work, indicated that the clinical pathogen microbes are more tolerant than standard microbes that might be due to the presence of indigenous compounds resistant against the plant extracts (Mahendra et al., 2016). According to literature have not scientific research about the antimicrobial activities of $P$. platychlaena but the essential oils from the fruits of $P$. ferulacea showed antibacterial activity against Staphylococus aureus, Eschrechia coli and Pseudomonas aeruginosa (Massumia et al., 2007). Other studies revealed the methanol extract of $P$. acaulis root has potent antibacterial activity against Streptococcus mutan (Nosrati et al., 2018). Generally, the variation in antimicrobial activities of $P$. platychlaena Boiss. might be due to the variation in the distributions of phytochemical compounds and the quantity of phytochemicals in each of root, leaves, stem and flowers of this plant. The petroleum ether extraction for the leaves and the flower ethanol extracts of the $P$. 
platychlaena Boiss. showed higher toxicity towards both bacteria and yeasts than extracts of other parts, this may be due to the presences of some compounds detected in our study, such as terpenoid, alkaloid, phenol, flavonoid, saponin and tannin, while other parts have less antimicrobial activities that may be due to the containing of less amount of the phytochemicals. The pure compound 5,8- dimethoxy psoralen, was an active compound isolated from $P$. platychlaena Boiss. having potential activity to inhibit the growth of bacteria and yeast pathogen. The differences in the susceptibility of both bacteria and yeast strains used in this work to the phytochemical compounds, may be attributed to the variation in the penetration rates of the phytochemicals through the cell wall, and cytoplasmic membrane of those organisms, one of the important properties of most compounds is causing the partition of the lipids of cell membrane of microbes and leakage of the cell contents leads to the damage of the intracellular structure of microbes (de Lira Mota et al., 2012) (Murbach Teles Andrade et al., 2013). According to literature have not scientific research about antioxidant activites of this species but in the previous years other studies conducted on other species of the same genus (Çoruh et al., 2007) have shown Prangos ferulacea Lindl. extracts have antioxidant properties with $\mathrm{IC}_{50}$ value of $0.24 \mathrm{mg} / \mathrm{ml}$. As well as, it has been reported (Ahmed et al., 2011) that the water extracts of Prangos ferulacea, P. heyniae, $P$. meliocarpoides var. meliocarpoides, and $P$. uechtritzii display low antioxidant activities than the methanol extract of Prangos species. Also, slight antioxidant activity was observed in the fruit of Prangos ferulacea (L.) (Cesur et al., 2017).

\section{Conclusion}

This is the first study performed on the extract of Prangos platychlaena Boiss. The results revealed the presence of terpenoids, alkaloids, polyphenols, flavonoids, saponins and tannins as major phytochemical groups distributed in different plant parts of $P$. platychlaena. As well as, the three compounds (5,8 dimethoxy psoralen, 5-Methoxy psoralen and 8-Methoxy psoralen) were isolated and purified from flowers of $P$. platychlaena Boiss. and recorded for the first time in this species. The extracts and isolated compounds of this plant have shown antioxidant and antimicrobial activities against common bacteria and yeast pathogen. In conclusion, more studies are necessary to isolate and purify the active compounds and to use their antimicrobial, antiinflammation and anticancer activities and more studies are required on the toxicology and pharmacology of crude extracts of this plant, the safety of isolated compounds should be assessed before clinical progression.

Acknowledgments. The authors thank Dr. Abdullah Shukur from the Biology department, College of Education, University of Salahadden, for helping in the identification of plant species.

Conflict of interests. The authors declare no conflict of interests.

\section{REFERENCES}

[1] Ahmed, D., Khan, M. M., Saeed, R. (2015): Comparative analysis of phenolics, flavonoids, and antioxidant and antibacterial potential of methanolic, hexanic and aqueous extracts from Adiantum caudatum leaves. - Antioxidants (Basel) 4(2): 394-409. 
[2] Ahmed, J., Guvenc, A., Kucukboyaci, N., Baldemir, A., Coskun, M. (2011): Total phenolic contents and antioxidant activities of Prangos Lindl. (Umbelliferae) species growing in Konya province (Turkey). - Turkish Journal of Biology 35: 353-360.

[3] Bacha, K., Tariku, Y., Gebreyesus, F., Zerihun, S., Mohammed, A., Weiland-Brauer, N., Schmitz, R. A., Mulat, M. (2016): Antimicrobial and anti-Quorum sensing activities of selected medicinal plants of Ethiopia: implication for development of potent antimicrobial agents. - BMC Microbiology 16(1): 1-9.

[4] Bankole, A. E., Adekunle, A. A., Sowemimo, A. A., Umebese, C. E., Abiodun, O., Gbotosho, G. O. (2016): Phytochemical screening and in vivo antimalarial activity of extracts from three medicinal plants used in malaria treatment in Nigeria. - Parasitol Res 115(1): 299-305.

[5] Cesur, C., Coşge Şenkal, B., Yaman, C., Uskutoğlu, T., Koç, M. (2017): Antioxidant activity of fruit extracts of Prangos ferulacea (L.) Lindl. from Turkey. - Journal of the Institute of Science and Technology 7(4): 249-256.

[6] Çoruh, N., Celep, A. G. S. d. 1., Özgökçe, F. (2007): Antioxidant properties of Prangos ferulacea (L.) Lindl., Chaerophyllum macropodum Boiss. and Heracleum persicum Desf. from Apiaceae family used as food in Eastern Anatolia and their inhibitory effects on glutathione-S-transferase. - Food Chemistry 100(3): 1237-1242.

[7] de Lira Mota, K. S., de Oliveira Pereira, F., de Oliveira, W. A., Lima, I. O., de Oliveira Lima, E. (2012): Antifungal activity of Thymus vulgaris L. essential oil and its constituent phytochemicals against Rhizopus oryzae: interaction with ergosterol. Molecules 17(12): 14418-14433.

[8] Desai, S. D., Desai, D. G., Kaur, H. (2009): Saponins and their biological activities. Pharma Times 41(3): 13-16.

[9] Dincel, D., Hatipoglu, S. D., Goren, A. C., Tocu, G. (2013): Anticholinesterase furocoumarins from Heracleum platytaenium, an endemic species to Idea mountains. Turkish Journal of Chemistry 37: 675-683.

[10] Ghazanfar, S. A., Edmondson, J. R. (2013): Flora of Iraq. - National Herbarium of Iraq of the Ministry of Agriculture, Baghdad 5(2): 109-220.

[11] Ginovyan, M., Petrosyan, M., Trchounian, A. (2017): Antimicrobial activity of some plant materials used in Armenian traditional medicine. - BMC Complementary and Alternative Medicine 17(1): 1-9.

[12] Giweli, A., Dzamic, A. M., Sokovic, M., Ristic, M. S., Marin, P. D. (2012): Antimicrobial and antioxidant activities of essential oils of Satureja thymbra growing wild in Libya. - Molecules 17(5): 4836-4850.

[13] Hamad, R., Balzter, H., Kolo, K. (2017): Multi-criteria assessment of land cover dynamic changes in Halgurd Sakran national park (HSNP), Kurdistan region of Iraq, using remote sensing and GIS. - Land 6(1): 1-17.

[14] Hossain, M. A., Al-Raqmi, K. A. S., Al-Mijizy, Z. H., Weli, A. M., Al-Riyami, Q. (2013): Study of total phenol, flavonoids contents and phytochemical screening of various leaves crude extracts of locally grown Thymus vulgaris. - Asian Pacific Journal of Tropical Biomedicine 3(9): 705-710.

[15] Irfan, M., Ahmed, S., Sharma, M. (2014): Antimicrobial activity of terpenoids from Sphaeranthus indicus. L. - Asian Journal of Plant Science and Research 4(1): 1-16.

[16] Juca, M. M., Filho, F. M. S. C., Almeida, J. C. d., Mesquita, D. d. S., Barriga, J. R. d. M., Dias, K. C. F., Barbosa, T. M., Vasconcelos, L. C., Leal, L. K. A. M., Ribeiro, J. e. E., Vasconcelos, S. M. M. (2018): Flavonoids: biological activities and therapeutic potential. - Natural Product Research 16: 1-14.

[17] Luz, R. F., Vieira, I. J. C., Braz-Filho, R., Moreira, V. F. (2015): 13C-NMR Data from coumarins from Moraceae family. - American Journal of Analytical Chemistry 6(11): 851-866. 
[18] Mahendra, A. D., Tirtodiharjo, K., Kusuma, I. T. D. (2016): The pattern of bacteria and its resistance on adult sepsis patient at Dr. Moewardi general hospital, Indonesia. Archives of Clinical Microbiology 7(5): 1-6.

[19] Mandal, S., Patra, A., Samanta, A., Roy, S., Mandal, A., Mahapatra, T. D., Pradhan, S., Das, K., Nandi, D. K. (2013): Analysis of phytochemical profile of Terminalia arjuna bark extract with antioxidative and antimicrobial properties. - Asian Pacific Journal of Tropical Biomedicine 3(12): 960-966.

[20] Mariem, S., Hanen, F., Inès, J., Mejdi, S., Riadh, K. (2014): Phenolic profile, biological activities and fraction analysis of the medicinal halophyte Retama raetam. - South African Journal of Botany 94: 114-121.

[21] Massumia, M. A., Fazelib, M. R., Alavic, S. H. R., Ajanid, Y. (2007): Chemical constituents and antibacterial activity of essential oil of Prangos ferulacea (L.) Lindl. Fruits. - Iranian Journal of Pharmaceutical Sciences 3: 171-176.

[22] Matsuura, H. N., Fett-Neto, A. G. (2015): Plant Alkaloids: Main Features, Toxicity, and Mechanisms of Action. - In: Gopalakrishnakone, P., Carlini, C., Ligabue-Braun, R. (eds.) Plant Toxins. Toxinology. Springer, Dordrecht.

[23] Mbah, J. A., Gatsing, D., M. N., Efange, S. (2010): Antibacterial agents from the seeds of Peucedanum zenkeri L. (Umbelliferae). - Pakistan Journal of Medical Sciences 26(2): 314-318.

[24] Moradi, M.-T., Rafieian-Kopaei, M., Karimi, A. (2016): A review study on the effect of Iranian herbal medicines against in vitro replication of herpes simplex virus. - Avicenna Journal Phytomedicine 5(6): 506-515.

[25] Mujeeb, F., Bajpai, P., Pathak, N. (2014): Phytochemical evaluation, antimicrobial activity, and determination of bioactive components from leaves of Aegle marmelos. BioMed Research International. https://doi.org/10.1155/2014/497606.

[26] Murbach Teles Andrade, B. F., Nunes Barbosa, L., da Silva Probst, I., Fernandes Júnior, A. (2013): Antimicrobial activity of essential oils. - Journal of Essential Oil Research 26(1): 34-40.

[27] Nosrati, M., Behbahani, M., Mohabatkar, H., Shakeran, z. (2018): Antibacterial and antibiofilm activities of Prangos acaulis Bornm. extract against Streptococcus mutans: an in silico and in vitro study. - Journal of Herbmed Pharmacology 7(3): 176-184.

[28] Silva, S. M., Abe, S. Y., Murakami, F. S., Frensch, G., Marques, F. A., Nakashima, a. T. (2011): Essential oils from different plant parts of eucalyptus cinerea F. Muell. ex Benth. (Myrtaceae) as a Source of 1,8-Cineole and their bioactivities. - Pharmaceuticals 4: 15351550.

[29] Singh, K. L., Bag, G. C. (2013): Phytochemical analysis and determination of total phenolics content in water extracts of three species of hedychium. - International Journal of PharmTech Research 5: 1516-1521.

[30] Sylvie, D. D., Anatole, P. C., Cabral, B. P., Veronique, P. B. (2014): Comparison of in vitro antioxidant properties of extracts from three plants used for medical purpose in Cameroon: Acalypha racemosa, Garcinia lucida and Hymenocardia lyrata. - Asian Pacific Journal of Tropical Biomedicine 4: 625-632.

[31] Wina, E., I. W. R., S., Tangendjaja, B. (2010): Biological activity of tannins from Acacia mangium bark extracted by different solvents. - Media Peternakan 33(2): 103-107. 


\section{APPENDIX}

Figure A1. IR spectrum of 5,8 dimethoxy psoralen (isopimpinellin)

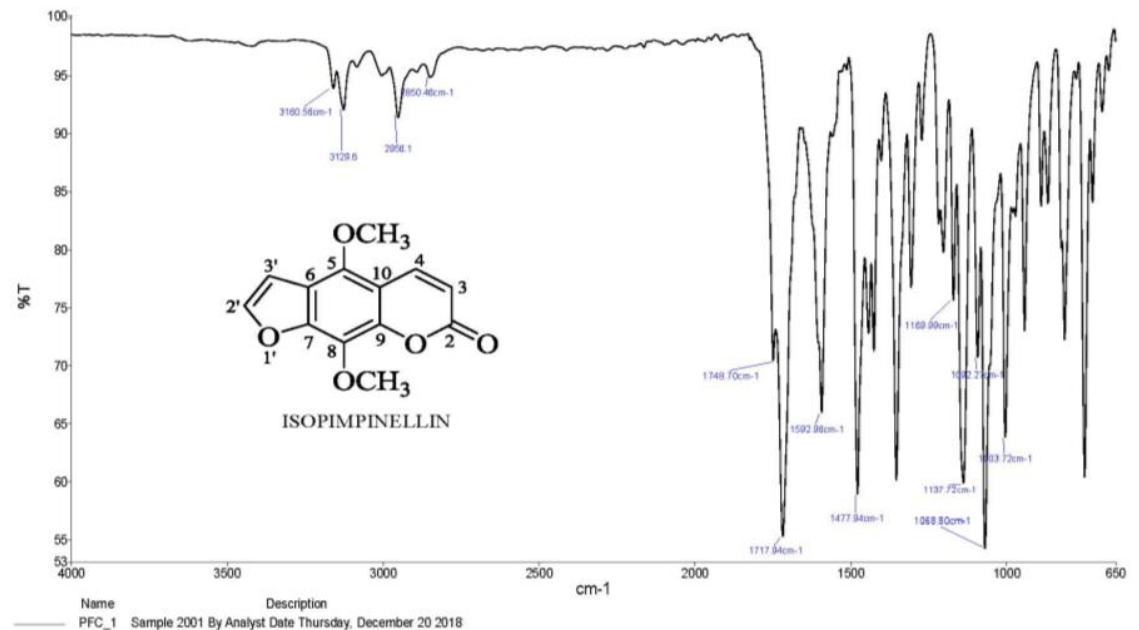

Figure A2. ${ }^{13}$ C-NMR spectrum of 5,8 dimethoxy psoralen (isopimpinellin)

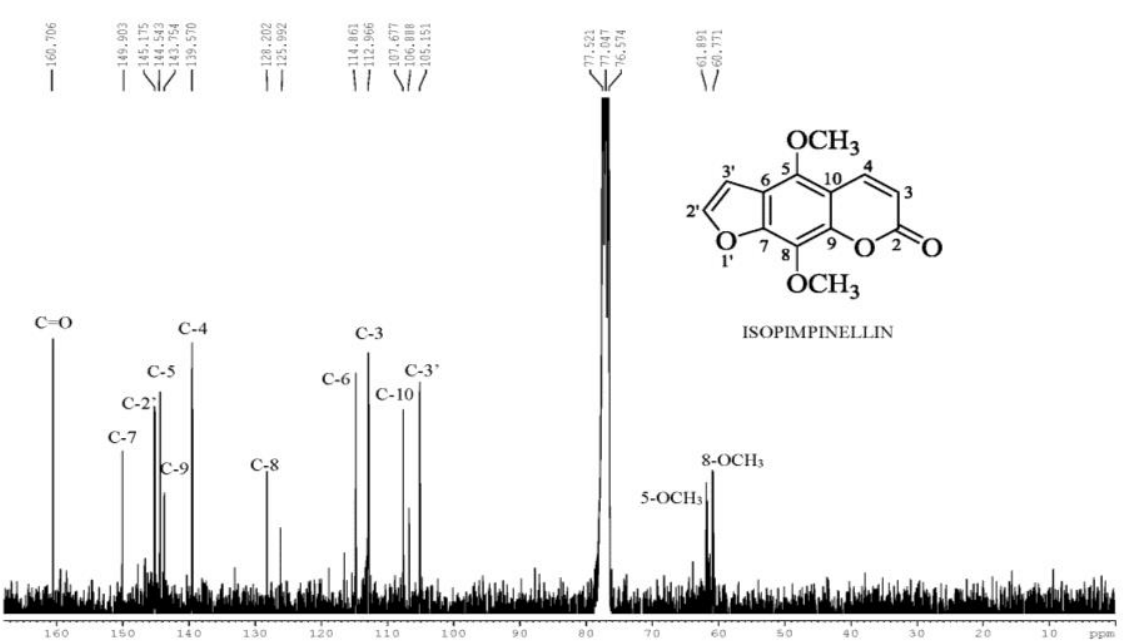

Figure A3. ${ }^{1}$ H-NMR spectrum of 5,8 dimethoxy psoralen (isopimpinellin)

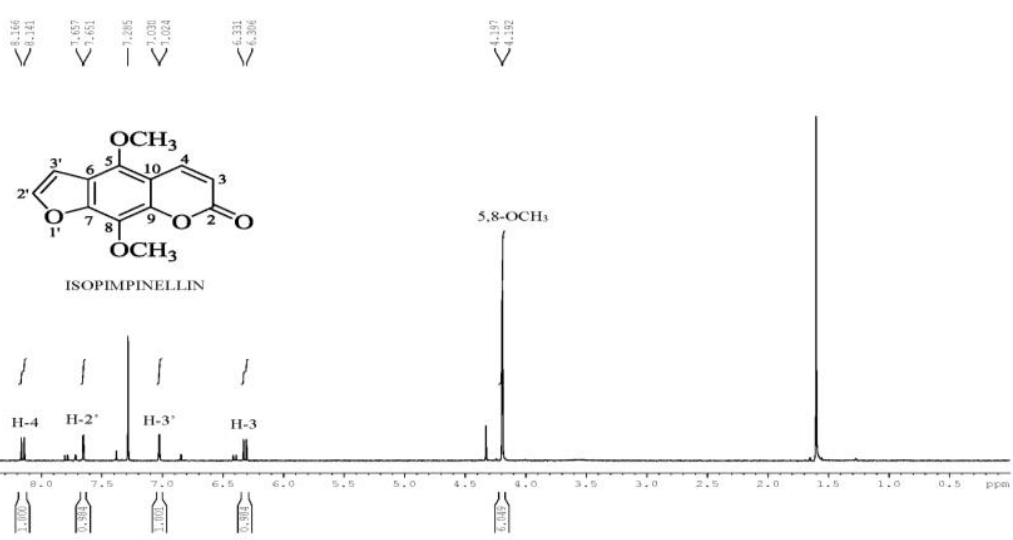

APPLIED ECOLOGY AND ENVIRONMENTAL RESEARCH 18(2):2425-2443.

http://www.aloki.hu • ISSN 15891623 (Print) • ISSN 17850037 (Online)

DOI: http://dx.doi.org/10.15666/aeer/1802_24252443

(C) 2020, ALÖKI Kft., Budapest, Hungary 
Figure A4. COSY spectrum of 5,8 di methoxy psoralen (isopimpinellin)

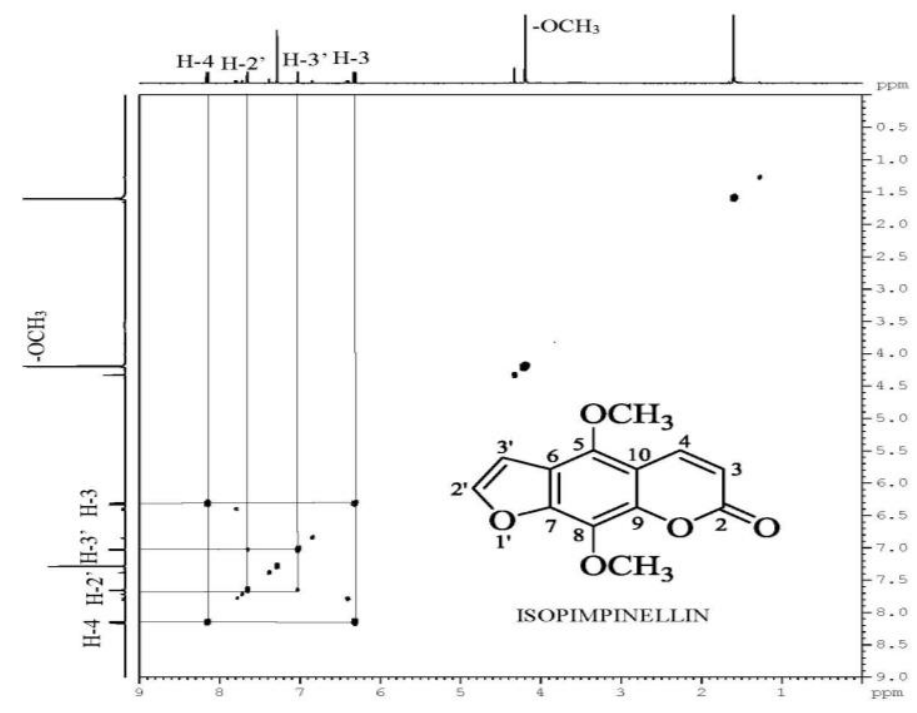

Figure A5. GC spectrum of 5,8 dimethoxy psoralen (isopimpinellin)

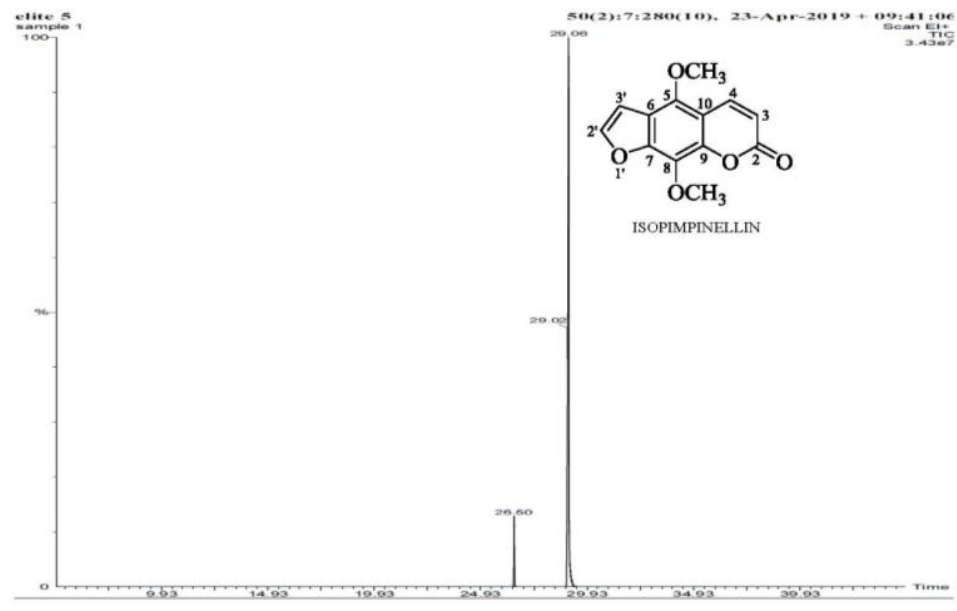

Figure A6. MS spectrum of 5,8 dimethoxy psoralen (isopimpinellin)

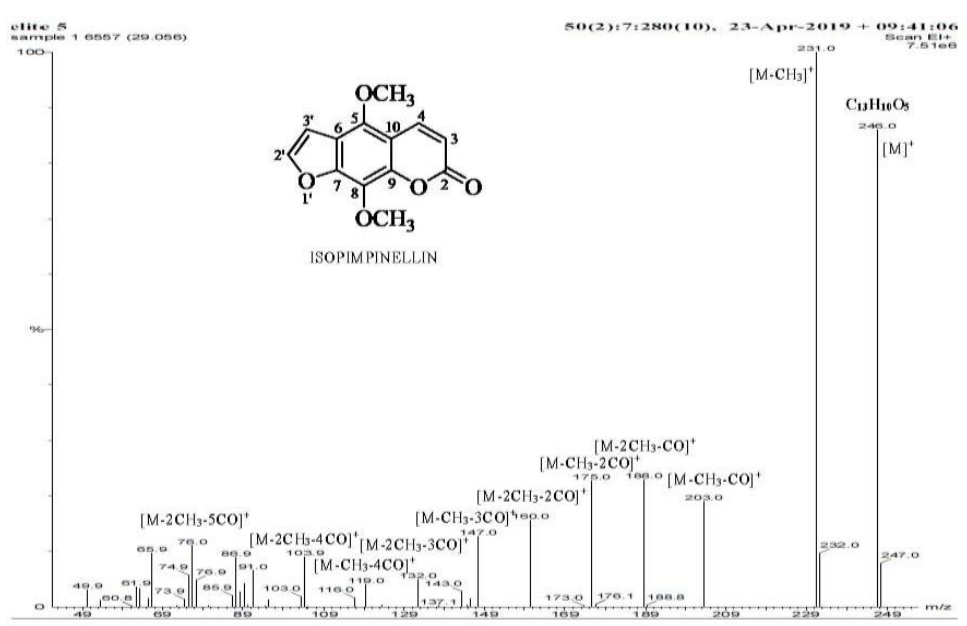

APPLIED ECOLOGY AND ENVIRONMENTAL RESEARCH 18(2):2425-2443. http://www.aloki.hu • ISSN 15891623 (Print) • ISSN 17850037 (Online) DOI: http://dx.doi.org/10.15666/aeer/1802_24252443 (C) 2020, ALÖKI Kft., Budapest, Hungary 
Figure A7. IR spectrum of 5-methoxy psoralen

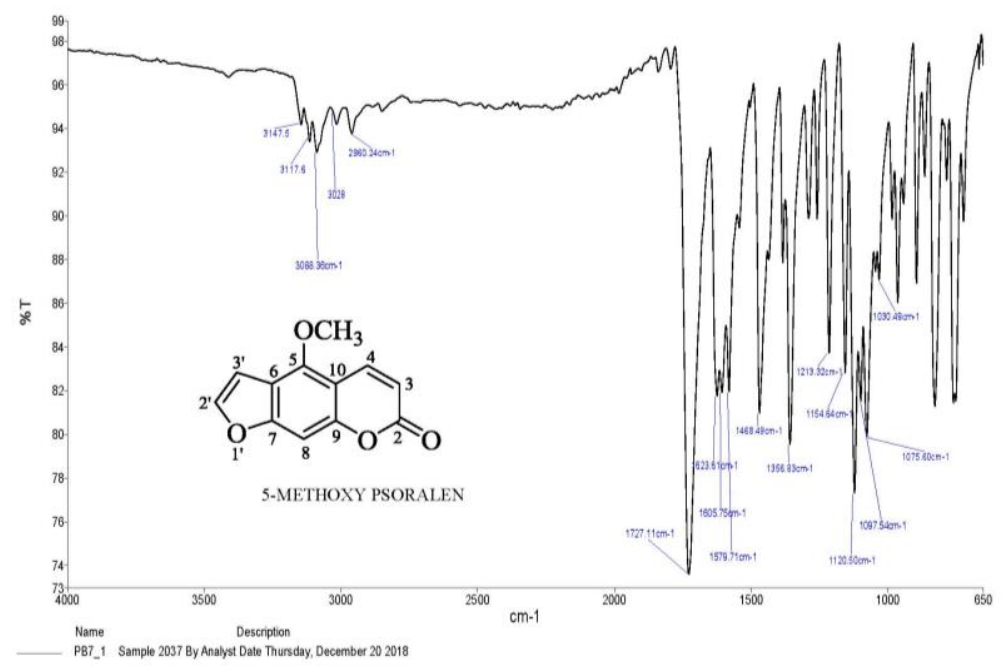

Figure A8. ${ }^{1} H$-NMR spectrum of 5-methoxy psoralen
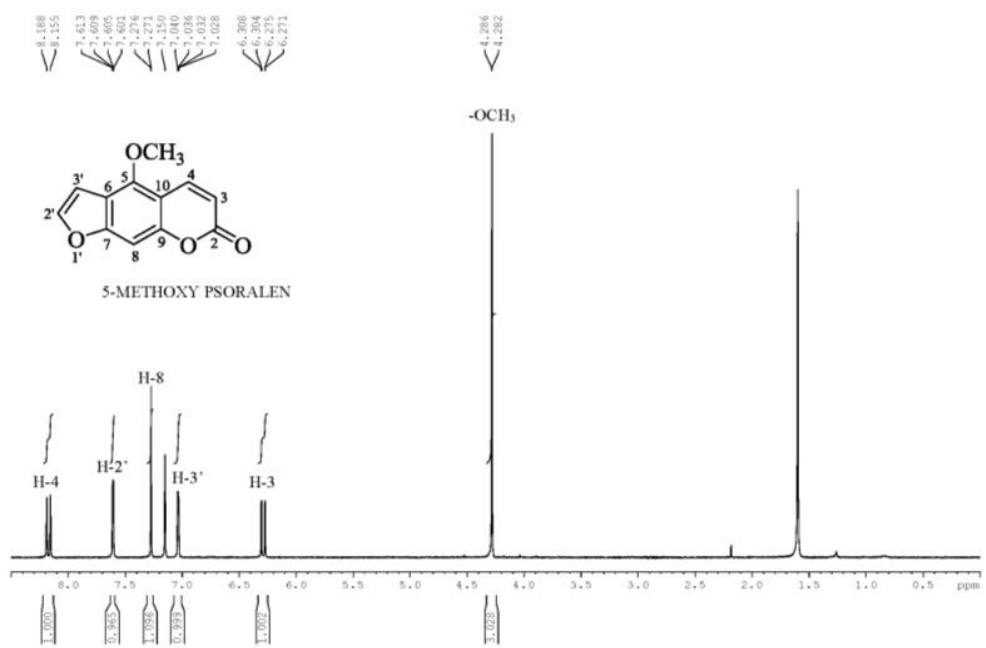

Figure A9. ${ }^{13}$ C-NMR spectrum of 5-methoxy psoralen

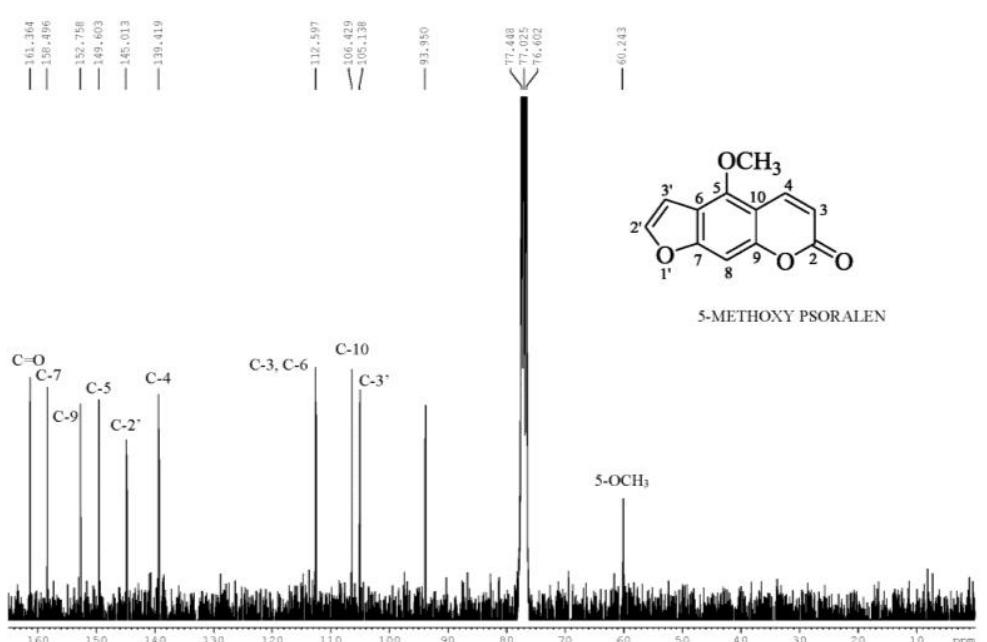

APPLIED ECOLOGY AND ENVIRONMENTAL RESEARCH 18(2):2425-2443.

http://www.aloki.hu • ISSN 15891623 (Print) • ISSN 17850037 (Online) DOI: http://dx.doi.org/10.15666/aeer/1802_24252443

(c) 2020, ALÖKI Kft., Budapest, Hungary 
Figure A10. COSY spectrum of 5-methoxy psoralen

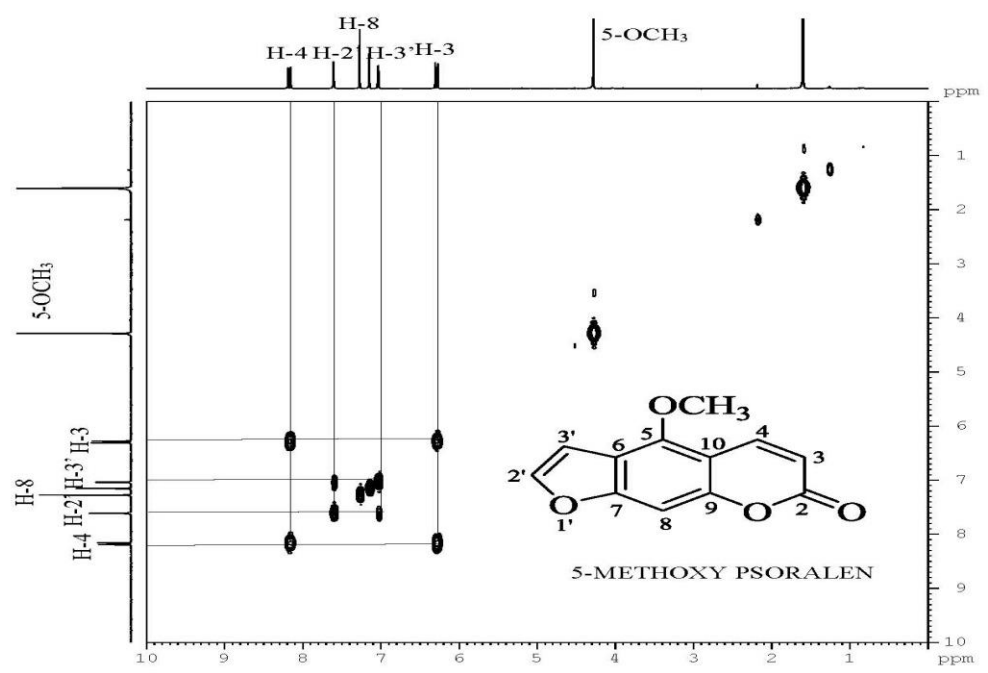

Figure A11. GC spectrum of 5-methoxy psoralen

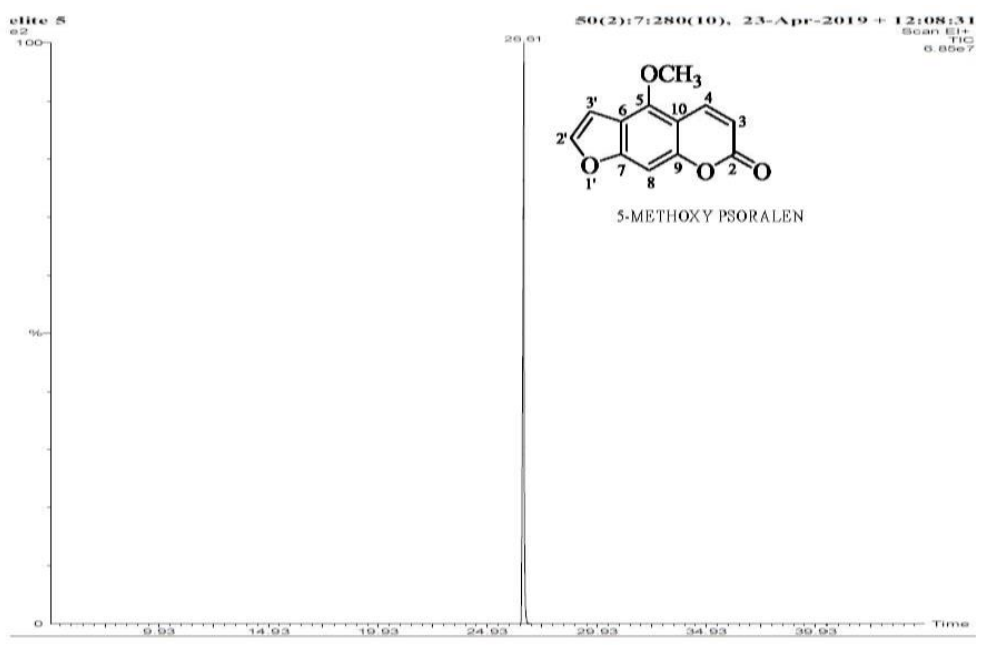

Figure A12. MS spectrum of 5-methoxy psoralen

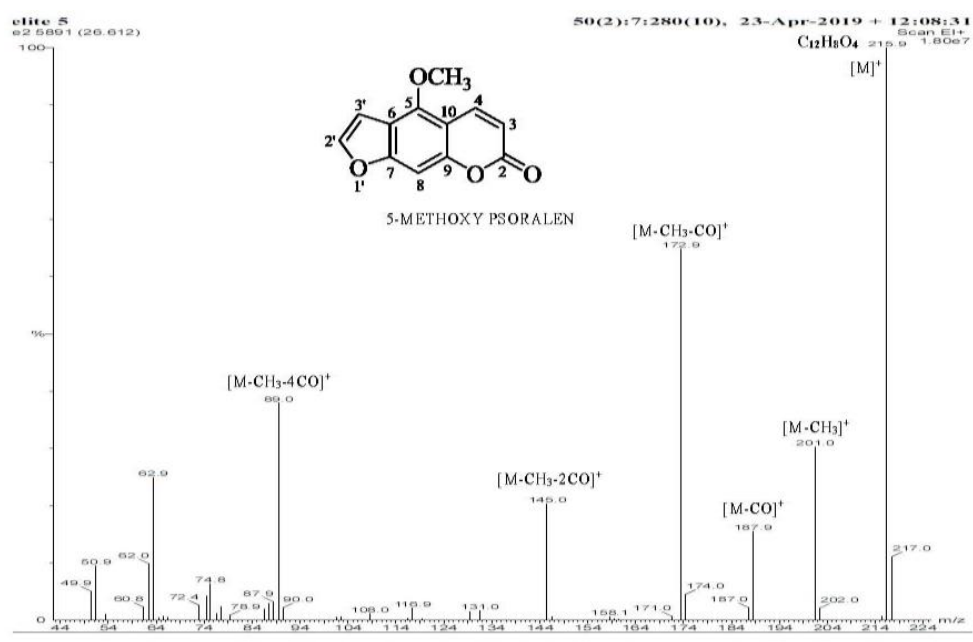

APPLIED ECOLOGY AND ENVIRONMENTAL RESEARCH 18(2):2425-2443.

http://www.aloki.hu • ISSN 15891623 (Print) • ISSN 17850037 (Online)

DOI: http://dx.doi.org/10.15666/aeer/1802_24252443

(c) 2020, ALÖKI Kft., Budapest, Hungary 
Figure A13. IR spectrum of 8-methoxy psoralen

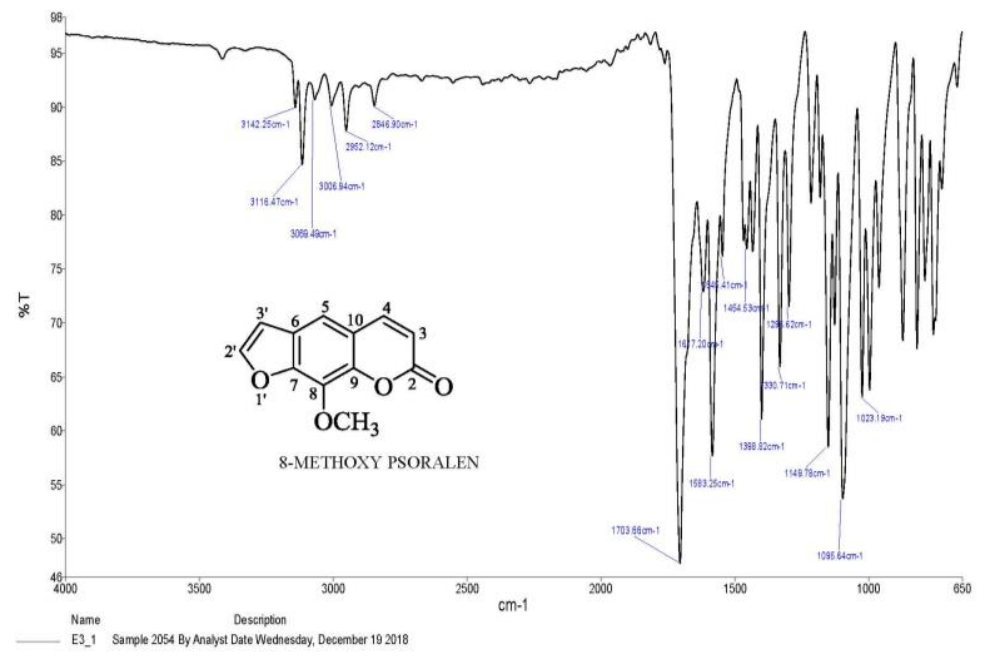

Figure A14. ${ }^{1} H$-NMR spectrum of 8-methoxy psoralen
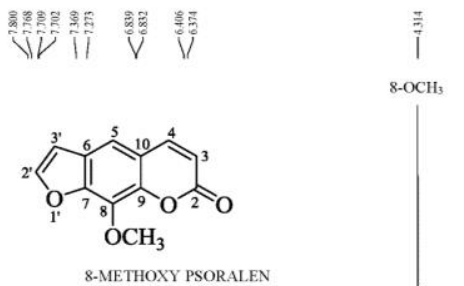

8-METHOXY PSORALEN

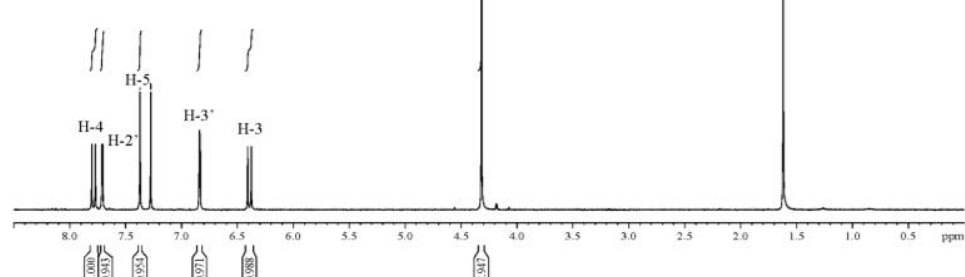

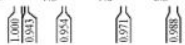

Figure A15. ${ }^{13} \mathrm{C}$-NMR spectrum of 8-methoxy psoralen

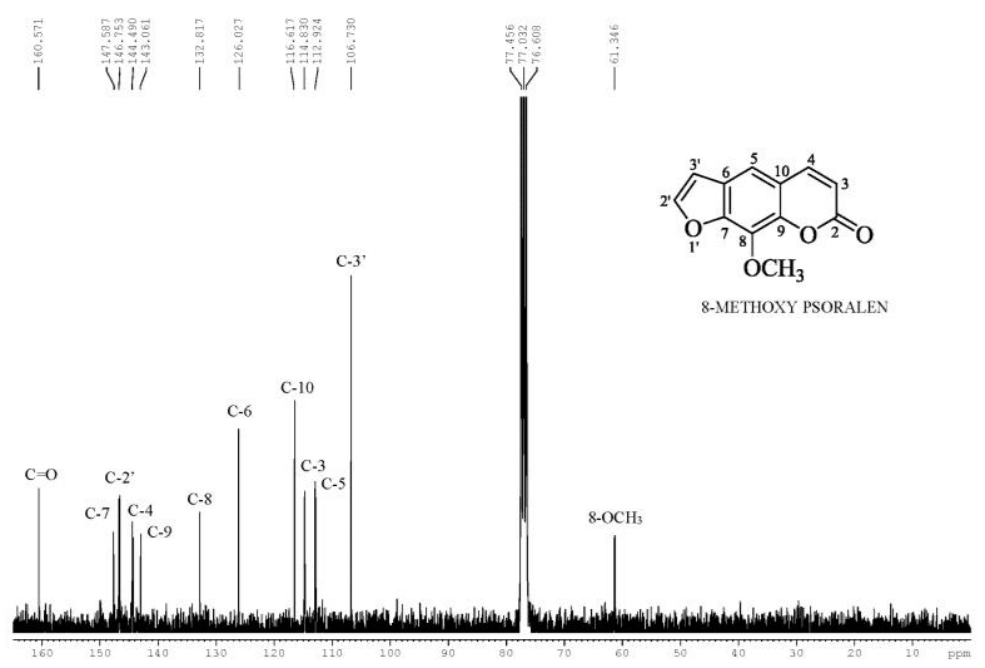

APPLIED ECOLOGY AND ENVIRONMENTAL RESEARCH 18(2):2425-2443.

http://www.aloki.hu • ISSN 15891623 (Print) • ISSN 17850037 (Online)

DOI: http://dx.doi.org/10.15666/aeer/1802_24252443

(c) 2020, ALÖKI Kft., Budapest, Hungary 
Figure A16. COSY spectrum of 8-methoxy psoralen

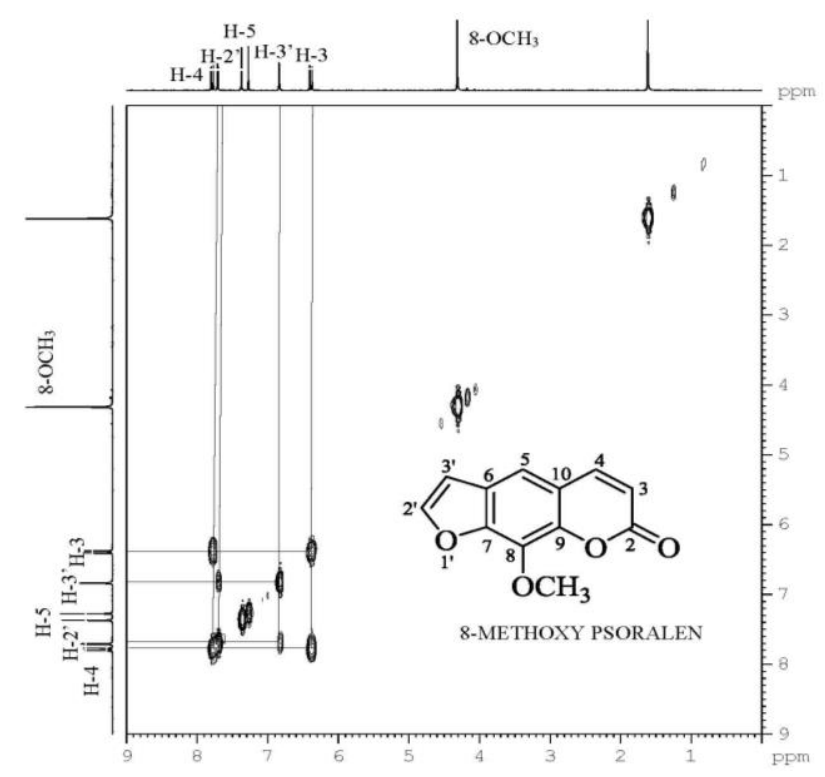

Figure A17. GC spectrum of 8-methoxy psoralen

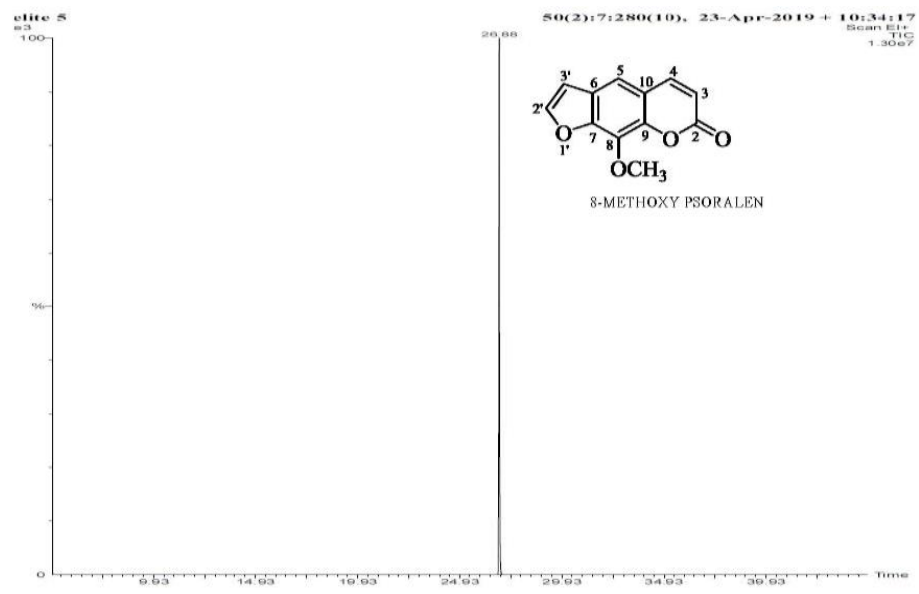

Figure A18. MS spectrum of 8-methoxy psoralen

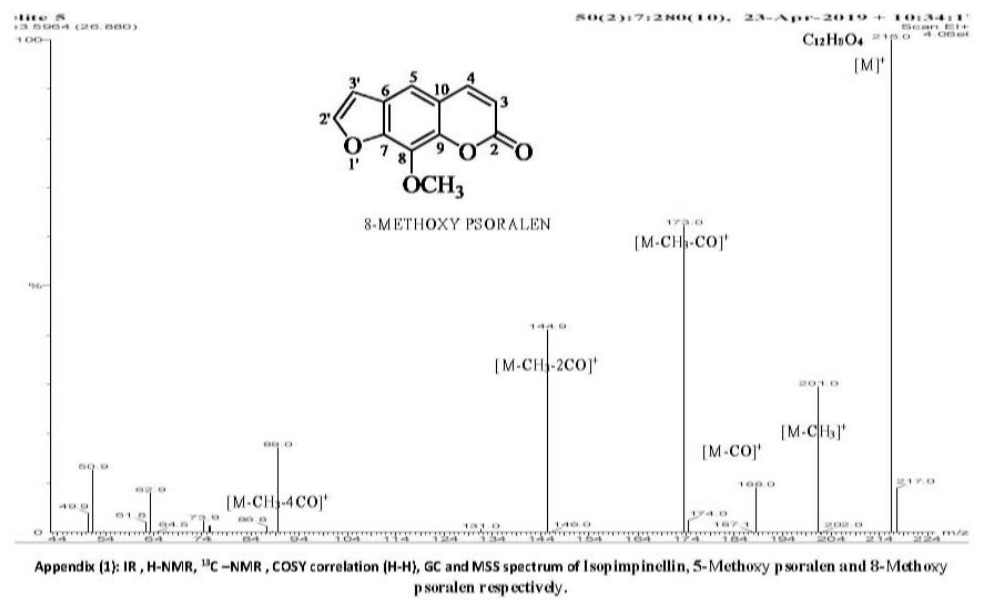

APPLIED ECOLOGY AND ENVIRONMENTAL RESEARCH 18(2):2425-2443.

http://www.aloki.hu • ISSN 15891623 (Print) • ISSN 17850037 (Online)

DOI: http://dx.doi.org/10.15666/aeer/1802_24252443

(c) 2020, ALÖKI Kft., Budapest, Hungary 